\title{
HUBUNGAN ANTARA ASUPAN ZAT GIZI DAN STATUS GIZI DENGAN KEJADIAN ANEMIA PADA REMAJA PUTRI
}

\section{RELATIONSHIP BETWEEN INTAKE NUTRITION AND NUTRITIONAL STATUS WITH INCIDENCE OF ANEMIA IN GIRLS}

\author{
${ }^{1}$ Arisanty Nursetia Restuti, ${ }^{2}$ Yoswenita Susindra \\ Progam Studi Gizi Klinik Jurusan Kesehatan, Negeri Jember \\ Jl. Mastrip PO. BOX 164 Jember \\ ${ }^{1}$ dr.arisanty@yahoo.co.id, ${ }^{2}$ wenisusindra@gmail.com
}

\begin{abstract}
Abstrak
Kebutuhan zat besi pada remaja putri lebih tinggi dibandingkan remaja putra, disebabkan remaja putri rutin mengalami menstruasi, sehingga remaja putri lebih rentan menderita anemia. Kebiasaan makan yang salah pada remaja putri merupakan penyebab anemia. Anemia gizi pada remaja putri dapat berakibat menurunnya kesehatan reproduksi. Tujuan dari kegiatan ini adalah mengetahui hubungan antara status gizi dan asupan zat gizi dengan kejadian anemia pada remaja putri.Jenis penelitian ini cross sectional Penelitian dilakukan di SMK Mahfilud Duror II Jelbuk pada bulan September sampai November tahun 2016. Pengambilan sampel dengan mengunakan metode accidental sampling. Kriteria inklusi yaitu remaja putri usia 14 - 18 tahun, tidak sedang menstruasi, tidak mengkonsumsi tablet Fe. Data yang dipakai adalah data asupan yang diperoleh dari hasil perhitungan food recall 2 (1 x 24 jam), data status gizi diperoleh dari perhitungan tinggi badan dan berat badan kemudian diukur indeks massa tubuh (IMT) bedasarkan usia, serta data anemia didapatkan hasil pemeriksaan darah metode quick cek Hb. Data diuji menggunakan uji Gamma.Hasil penelitian didapatkan dari 109 siswi, 71 orang yang masuk kriteria inklusi, sedangkan 38 orang tereklusi karena sedang menstruasi. Uji hubungan antara status gizi dengan kejadian anemia didapatkan $\mathrm{p}=0,36$ yang artinya tidak ada hubungan yang signifikan, sedangkan uji hubungan antara asupan energi, karbohidrat, protein, lemak, vitamin $\mathrm{C}$ didapatkan nilai $\mathrm{p}>0,05$ artinya tidak ada hubungan yang signifikan. Meningkatnya konsumsi makanan olahan yang nilai gizinya kurang, namun memiliki banyak kalori Konsumsijunk food merupakan penyebab para remaja rentan sekali kekurangan zat gizi tertentu meskipun status gizi normal.
\end{abstract}

Kata Kunci :anemia, asupan zat gizi, remaja putri, status gizi

\section{Abstract}

The iron requirement more high for girls than boys, because girls menstruate regularly, so that the girls more prone to suffer from anemia. Wrong eating habits on girls is a cause of anemia. Nutritional anemia girls can be decline in reproductive health. The purpose of this research is know relations activities between nutritional status and nutrient intake with incidence anemia on girls. This research operates a cross-sectional study was conducted at SMK Mahfilud Duror II Jelbuk during of septemberuntil november 2016. Sampling with uses accidental sampling method. That inclusion criteria age 14-18 years girls, not menstruating, not consume iron tablet. Intake nutrient findings from calculation food recall 2 ( 1 x 24 hours), nutritional status finding from calculations height and weight then measured the body mass index (BMI)/age, as well as the data anemia results obtained blood examination method quick check Hb. Data were tested using gamma test. Results from 109 students, 71 girls inclusion criteria, while 38 girls exclude because she was menstruating. Relationship test between the incidence of anemia with nutritional status was obtained $\mathrm{p}=0.36$ that means no relations significantly, while the relationship test between energy intake, carbohydrate, protein, fat, vitamin $\mathrm{C}$ obtained $\mathrm{p}$ value $>0.05$ means no significant relationships. Increased consumption of processed foods which less nutritional value, but it has a lot of calories consumption of junk food is a cause girls susceptible once dietary deficiencies certain although normal nutritional status.

Keywords: anemia, nutrient intake, girls, nutritional status

\section{PENDAHULUAN}

Indonesia dihadapkan pada masalah gizi, diantaranya adalah anemia gizi, kekurangan vitamin A, kekurangan energi, protein dan kekurangan iodium. Diantara 5 (lima) masalah di atas, maka yang sering terjadi sampai saat ini adalah anemia gizi (Proverawati dan Kusumawati, 2010).

Anemia masih merupakan masalah kesehatan masyarakat yang banyak terjadi dan tersebar di seluruh dunia terutama di negara berkembang dan negara miskin (Bakta, 2006). Kejadian anemia banyak terjadi terutama pada usia remaja baik kelompok pria maupun wanita. Di Indonesia prevalensi anemia gizi besi pada remaja putri usia 13-18 tahun sebesar 22,7 \% (Kemenkes RI, 2013), sedangkan di Jawa timur 50 - $60 \%$ remaja putri mengalami anemia (Hankusuma, 2009). Prevalensi yang lebih dari $15 \%$ ini menyebabkan anemia pada remaja putri menjadi salah satu masalah kesehatan utama di Indonesia (Kemenkes RI, 2013).

Prevalensi anemia gizi besi yang tinggi antara lain disebabkan oleh beberapa faktor yaitu: kehilangan darah secara kronis, asupan zat besi tidak cukup, penyerapan yang tidak adekuat dan peningkatan kebutuhan akan zat besi (Sulistyoningsih, 2011). Remaja putri menderita anemia biasanya dikarenakan sedang dalam masa pertumbuhan dimana 
membutuhkan zat gizi lebih tinggi baik zat gizi makro maupun mikro (Arisman, 2009; Badriah, 2011). Pada remaja putri terjadi peningkatan

dan Ruslianti, 2013). Anemia yang disebabkan karena kurangnya asupan zat gizi sehari-hari pada remaja putri ini dipengaruhi oleh ketersediaan bahan pangan dan pola makan yang salah, dimana pada remaja putri sering pantang terhadap makanan tertentu atau mengurangi jumlah makanan yang dikonsumsi, karena faktor ingin langsing (Marmi, 2013).Kebiasaan makan yang salah ini merupakan penyebab terjadinya anemia pada remaja putri (Adriani dan Wirjatmadi, 2012). Anemia yang disebabkan karena kekurangan asupan zat gizi ditandai dengan adanya gangguan dalam sintesis hemoglobin. Zat gizi yang bersangkutan adalah protein, piridoksin (vitamin B6) yang mempunyai peran sebagai katalisator dalam sintesis heme di dalam molekul hemoglobin, selain itu zat besi $(\mathrm{Fe})$ merupakan salah satu unsur gizi sebagai komponen pembentukan hemoglobin atau membentuk sel darah merah (Bakta, 2006).

Status gizi (nutrition status) dapat didefinisikan sebagai ekspresi dari keadaan keseimbangan antara konsumsi dan penyerapan zat gizi dan penggunaan zat - zat gizi tersebut (Supariasa, 2012). Kekurangan zat gizi makro seperti : energi dan protein, serta kekurangan zat gizi mikro seperti : zat besi (Fe), yodium dan vitamin A maka akan menyebabkan anemia gizi, dimana zat gizi tersebut terutama zat besi (Fe) merupakan salah satu dari unsur gizi sebagai komponen pembentukan hemoglobin $(\mathrm{Hb})$ atau sel darah merah. Anemia gizi pada remaja putri berkaitan dengan menurunnya kesehatan reproduks (Badriah, 2011). Hal ini berkaitan dengan angka kejadian kehamilan pada remaja putri cukup tinggi dan cenderung meningkat (Adriani dan Wirjatmadi, 2012). Apabila remaja putri yang mengalami anemia kemudian hamil maka berpotensi melahirkan bayi dengan berat badan lahir rendah. Selain itu anemia pada kehamilan juga dapat menyebabkan kematian baik ibu maupun bayi pada proses persalinan (Badriah, 2011; Sulistyoningsih, 2011; Marmi, 2013). Melihat begitu pentingnya anemia pada remaja putri maka peneliti ingin melihat hubungan antara asupan, status gizi dengan kejadian anemia pada remaja putri.

\section{METODOLOGI}

Jenis penelitian ini adalah penelitian analitik observasional dengan pendekatan cross sectional. Pada penelitian akan dilakukan pengukuran dan pengamatan terhadap sampel yang berbeda disaat yang bersamaan.

Penelitian ini akan dilakukan di SMK Mahfilud Duror II Jelbuk pada bulan September sampai November tahun 2016

Populasi penelitian yaitu remaja putri di SMK Mahfilud Duror II. Pengambilan sampel dengan mengunakan metode accidental sampling. Kriteria inklusi sampel penelitian yaitu remaja putri dengan rentang usia 16 - 18 tahun, tidak sedang menstruasi, tidak mengkonsumsi tablet Fe. Sedangkan untuk kriteria eksklusinya yaitu remaja putri yang menderita penyakit yang berat seperti (tumor/ kanker, ginjal, infeksi nematode usus, kelainan darah, dan gastritis kronis), tidak menderita penyakit dalam 1 bulan yang lalu seperti (rawat inap di rumah sakit atau puskesmas), kadar $\mathrm{Hb}<7 \mathrm{mg} / \mathrm{dl}$ (anemia berat).

Data yang dipakai dalam penelitian ini adalah data asupan yang diperoleh dari hasil perhitungan food kebutuhan akan zat besi lebih tinggi dari pria, untuk pembentukan sel darah merah, karena remaja putri rutin mengalami menstruasi setiap bulannya (Istiany recall 2 (1 x 24 jam), data status gizi diperoleh dari perhitungan tinggi badan dan berat badan kemudian diukur indeks massa tubuh (IMT) bedasarkan usia, serta data anemia didapatkan hasil pemeriksaan darah menggunakan metode quick cek $\mathrm{Hb}$. Sedangkaninstrumen yang digunakan dalam penelitian ini meliputi, lembar kuesioner, microtoise, timbangan dan lembar food recall.

Data penelitian dikumpulkan dengan teknik wawancara, kuesioner recall 2 × 24 jam, pengukuran tinggi badan dan berat badan serta hasil pemeriksaan laboratorium. Teknik wawancara dilakukan untuk mendapatkan data tentang karakteristik responden meliputi umur, status menstruasi, mengkonsumsi tablet $\mathrm{Fe}$, penyakit penyerta dan riwayat rawat inap. Data asupan didapatkan melalui metode wawancara dan perhitungan food recall 2 × 24 jam. Data status gizi didapatkan dari perhitungan IMT dari tinggi badan dibagi berat badan yang dibandingkan dengan usia. Sedangkan data $\mathrm{Hb}$ didapatkan dari pemeriksaan darah menggunakan metode quick cek $\mathrm{Hb}$.

Data yang didapat akan diuji hubungan antara asupan dan status gizi dengan anemia diuji menggunakan uji gamma.

\section{HASIL DAN PEMBAHASAN}

Penelitian ini menggunakan teknik pengambilan sampel dengan cara incidental sampling. Dari 109 siswi yang hadir dan bersedia menjadi subyek penelitian didapatkan 71 orang siswi yang masuk kriteria inklusi, sedangkan 38 orang siswi tereklusi dikarenakan sedang menstruasi. Subyek penelitian yang sesuai kriteria inklusi berjumlah 71 orang dengan karakteristik sebagai berikut :

\section{a. Karakteristik Subyek}

Dalam penelitian ini didapatkan data umur siswi dengan frekuensi paling besar subyek berumur 16 tahun sebanyak 23 orang $(32,4 \%)$, sebanyak 22 orang $(31 \%)$ berumur 15 tahun, sedangkan sebagian kecil subyek berusia 14 tahun sebanyak 3 orang $(4,2 \%)$ dan sebanyak 2 orang $(2,8 \%)$ subyek berumur 18 tahun (tabel 5.1). Remaja adalah periode perkembangan dimana individu mengalami perubahan dari masa kanak-kanak menuju masa dewasa biasanya antara usia 13 - 20 tahun (Potter dan Perry, 2005). Masa peralihan dari yang sangat bergantung dengan orang tua ke masa yang penuh tanggung jawab serta keharusan untuk sanggup berdiri sendri. Remaja berada dalam status interim sebagai akibat dari posisi yang diberikan oleh orang tua dan masyarakat dan melalui usaha nya sendiri yang selanjutnya memberikan prestasi tertentu bagi dirinya (Soetjiningsih, 2005).

Tabel 1 Distribusi Frekuensi menurut Umur

\begin{tabular}{ccc}
\hline Umur & Frekuensi & Persentase (\%) \\
\hline 14 & 3 & 4.2 \\
15 & 22 & 31 \\
16 & 23 & 32,4 \\
17 & 21 & 29,6 \\
18 & 2 & 2,8 \\
\hline Total & 71 & 100 \\
\hline
\end{tabular}

Sumber : Analisis data primer 2016

Distribusi frekuensi status gizi yang didapatkan adalah sebagian besar subyek mempunyai status gizi normal sebanyak 62 orang $(87,3 \%)$, sedangkan yang paling sedikiti subyek yang mempunyai status gizi kurus dan sangat kurus masing - masing 1 orang 
$(1,4 \%)$. Kebutuhan gizi remaja relatif besar, karena remaja masih mengalami masa pertumbuhan. Selain itu, remaja umumnya melakukan aktifitas fisik lebih tinggi dibandingkan dengan usia lainnya, sehingga diperlukan zat gizi yang lebih banyak (Sulistyoningsih,2011)

Tabel 2 Distribusi Frekuensi Status Gizi

\begin{tabular}{ccc}
\hline Status Gizi & Frekuensi & $\begin{array}{c}\text { Persentase } \\
(\%)\end{array}$ \\
\hline Kurus & 1 & 1,4 \\
Sangat Kurus & 1 & 1,4 \\
Normal & 62 & 87,3 \\
Gemuk & 7 & 9,9 \\
\hline Total & 71 & 100 \\
\hline
\end{tabular}

Sumber : Analisis data primer 2016

Hasil penelitian menunjukkan sebagian besar, remaja memiliki status gizi normal. Hal in menunjukkan bahwa sebagian besar siswi di SMK Mahfilud duror II mengerti tentang asupan yang di konsumsi setiap hari, sehingga sedikit yang mengalami gangguan makan atau nutrisi yang tidak tercukupi. Kebutuhan khusus nutrient perlu diperhatikan pada kelompok remaja yang memiliki aktivitas olahraga, mengalami kehamilan, gangguan perilaku makan, restriksi asupan makan, konsumsi alkohol, obat-obatan maupun hal-hal lain yang bisa terjadi pada remaja. Bagi remaja, makanan merupakan suatu kebutuhan pokok untuk pertumbuhan dan perkembangan tubuhnya. Kekurangan konsumsi makanan baik secara kuantitatif maupun kualitatif, akan menyebabkan gangguan proses metabolisme tubuh, yang mengarah pada timbulnya suatu penyakit.

Tabel 3. Distribusi Frekuensi Kejadian Anemia

\begin{tabular}{ccc}
\hline $\begin{array}{c}\text { Kejadian } \\
\text { anemia }\end{array}$ & Frekuensi & $\begin{array}{c}\text { Persentase } \\
(\%)\end{array}$ \\
\hline Anemia & 21 & 29,6 \\
Tidak & 50 & 70,4 \\
Anemia & 71 & 100 \\
\hline Total &
\end{tabular}

Sumber : Analisis data primer 2016

Tabel 3 menunjukkan hasil distribusi frekuensi derajat anemia subyek, yang didapatkan hasil subyek yang anemia sebanyak 50 siswi $(70,4 \%)$ dan yang tidak anemia sebanyak 21 siswi $(29,6 \%)$. Anemia biasanya terdeteksi atau setidaknya dikonfirmasi dengan menghitung sel darah lengkap. Secara umum, analisa sel darah lengkap dilakukan oleh dokter atau teknisi laboratorium dengan melihat slide kaca dibuat dari sampel darah di bawah mikroskop. Saat ini, banyak pemeriksaan ini dilakukan secara otomatis dan dilakukan oleh mesin.

Sebagian besar subyek tidak anemia, yang didapatkan dari hasil tes hemoglobin menggunakan alat digital yaitu quick check. Namun 21 sisw mengalami anemia, hal ini disebabkan karena ketidaksesuaian antara asupan dan aktifitas siswi. Karena sebagain diantaranya berada di Pondok Pesantren, dimana mereka tidak dapat memilih asupan yang ingin di makan. Penghancuran sel darah merah yang berlebihan dapat disebabkan oleh masalah dengan sumsum tulang seperti limfoma, leukemia, atau multiple myeloma, masalah dengan system kekebalan tubuh, Kemoterapi, dan Penyakit kronis seperti AIDS

Hasil penelitian menunjukkan asupan energi subyek yang terbanyak adalah defisit yaitu 64 orang (90,1\%), sedangkan asupan energi kategori kurang sebanyak 4 orang $(5,6 \%)$ dan kategori sedang sebanyak 3 orang $(4,2 \%)$, sedangkan yang termasuk asupan energi kategori baik tidak ada.
Tabel 4 Distribusi Frekuensi Asupan Energi

\begin{tabular}{ccc}
\hline Asupan Energi & Frekuensi & Persentase $(\%)$ \\
\hline Defisit & 64 & 90,1 \\
Kurang & 4 & 5,6 \\
Sedang & 3 & 4,2 \\
Baik & 0 & 0 \\
\hline Total & 71 & 100
\end{tabular}

Sumber : Analisis data primer 2016

Hasil penelitian menunjukkan asupan karbohidrat subyek yang terbanyak adalah defisit yaitu 61 orang $(85,9 \%)$, sedangkan asupan karbohidrat kategori kurang sebanyak 6 orang $(8,5 \%)$ dan kategori sedang sebanyak 2 orang $(2,8 \%)$, sedangkan yang termasuk asupan karbohidrat kategori baik sebanyak 2 orang (2,8\%).

Tabel 5 Distribusi Frekuensi Asupan Karbohidrat

\begin{tabular}{ccc}
\hline Asupan Energi & Frekuensi & Persentase (\%) \\
\hline Defisit & 61 & 85,9 \\
Kurang & 6 & 8,5 \\
Sedang & 2 & 2,8 \\
Baik & 2 & 2,8 \\
\hline Total & 71 & 100 \\
\hline
\end{tabular}

Sumber : Analisis data primer 2016

Hasil penelitian menunjukkan asupan lemak subyek yang terbanyak adalah defisit yaitu 61 orang $(85,9 \%)$, sedangkan asupan lemak kategori kurang sebanyak 4 orang $(5,6 \%)$ dan kategori sedang sebanyak 4 orang $(5,6 \%)$, sedangkan yang termasuk asupan lemak kategori baik sebanyak 2 orang $(2,8 \%)$.

Tabel 6. Distribusi Frekuensi Asupan Lemak

\begin{tabular}{ccc}
\hline Asupan Energi & Frekuensi & Persentase $(\%)$ \\
\hline Defisit & 61 & 85,9 \\
Kurang & 4 & 5,6 \\
Sedang & 4 & 5,6 \\
Baik & 2 & 2,8 \\
\hline Total & 71 & 100 \\
\hline
\end{tabular}

Sumber : Analisis data primer 2016

Hasil penelitian menunjukkan asupan protein subyek yang terbanyak adalah defisit yaitu 50 orang $(85,9 \%)$, sedangkan asupan protein kategori kurang dan sedang masing - masing sebanyak 8 orang $(11,3 \%)$, sedangkan yang termasuk asupan protein kategori baik sebanyak 5 orang $(7 \%)$.

Tabel 7. Distribusi Frekuensi Asupan Protein

\begin{tabular}{ccc}
\hline Asupan Energi & Frekuensi & Persentase $(\%)$ \\
\hline Defisit & 50 & 70,4 \\
Kurang & 8 & 11,3 \\
Sedang & 8 & 11,3 \\
Baik & 5 & 7 \\
\hline Total & 71 & 100
\end{tabular}

Sumber : Analisis data primer 2016

Hasil penelitian menunjukkan asupan vitamin $\mathrm{C}$ subyek yang terbanyak adalah defisit yaitu 68 orang $(95,8 \%)$, sedangkan asupan vitamin C kategori sedang sebanyak 3 orang $(4,2 \%)$, sedangkan yang termasuk asupan kategori kurang dan baik tidak ada.

Tabel 8 Distribusi Frekuensi Asupan Vitamin C

\begin{tabular}{ccc}
\hline Asupan Energi & Frekuensi & Persentase $(\%)$ \\
\hline Defisit & 68 & 95,8 \\
Kurang & 0 & 0 \\
Sedang & 3 & 4,2 \\
Baik & 0 & 0 \\
\hline Total & 71 & 100
\end{tabular}

Sumber : Analisis data primer 2016

Penelitian ini juga mengukur asupan zat besi dan Zn yang merupakan salah satu unsur untuk pembentukan hemoglobin (sel darah). Dari hasil penelitian didapatkan asupan zat besi dan Zinc pada seluruh subjek dalam kategori defisit (100\%). 
Hasil penelitian ini didapatkan sebagian besar asupan zat gizi dalam kategori defisit mulai dari asupan energi, karbohidrat, lemak, protein, zat besi,

sering ditemukan pada masa remaja adalah kekurangan energi dan protein, anemia gizi besi dan defisiensi berbagai vitamin dan mineral (Adriani dan Wiratmadji, 2012). Penelitian yang dilakukan oleh Klau dkk (2012) tentang asupan zat gizi pada remaja mendapatkan hasil yang hampir sama dengan penelitian ini yaitu persentase asupan energi, protein, lemak dan karbohidrat sebagian besar termasuk kategori kurang $(<80 \% \mathrm{AKG})$.

b. Hubungan antara Status Gizi dengan Kejadian Anemia

Dari hasil penelitian didapatkan analisis data hubungan antara status gizi dan kejadian anemia dengan uji non parametrik gamma didapatkan nilai Sig $(0,36)>(\alpha) 0,05$ maka Ho diterima dan Hi ditolak dengan koefisien korelasi sebesar 0,354 yang artinya adalah tidak ada hubungan yang signifikan antara status gizi dengan kejadian anemia.

Tabel 9 Hubungan antara Status Gizi dan Kejadian Anemia

\begin{tabular}{|c|c|c|c|c|c|c|}
\hline \multirow{2}{*}{$\begin{array}{c}\text { Kejadia } \\
\text { n } \\
\text { Anemi } \\
\text { a } \\
\end{array}$} & \multicolumn{4}{|c|}{ Status Gizi (IMT/U) } & \multirow{2}{*}{$\begin{array}{c}\text { Koefisie } \\
n \\
\text { Korelasi } \\
\text { (r) }\end{array}$} & \multirow[b]{2}{*}{$\begin{array}{l}\text { Nila } \\
\text { i p }\end{array}$} \\
\hline & $\begin{array}{c}\text { Sang } \\
\text { at } \\
\text { kurus }\end{array}$ & $\begin{array}{c}\text { Kuru } \\
\mathrm{s}\end{array}$ & $\begin{array}{c}\text { Norm } \\
\text { al }\end{array}$ & $\underset{\mathrm{k}}{\mathrm{Gemu}}$ & & \\
\hline Tidak & & & & & \multirow{4}{*}{0,354} & \multirow{4}{*}{0,36} \\
\hline Anemi & 0 & 0 & 45 & 5 & & \\
\hline $\begin{array}{c}\mathrm{a} \\
\text { Anemi } \\
\mathrm{a}\end{array}$ & 1 & 1 & 17 & 2 & & \\
\hline Jumlah & 1 & 1 & 62 & 7 & & \\
\hline
\end{tabular}

Hasil penelitian menunjukkan sebanyak 45 subyek memiliki status gizi normal dan tidak anemia, namun masih terdapat 17 subyek yang memiliki status gizi normal tetapi anemia, penyebab anemia tidak hanya disebabkan oleh asupan tetapi juga faktor genetik atau karena penyakit. Kebiasaan makan pada remaja putri yang salah juga berpengaruh terhadap pemenuhan kebutuhan dan status gizi. Dimana remaja putri sering mengkonsumsi junk food yang kaya akan kandungan energi tetapi sangat minim kandungan vitamin dan mineral sehingga belum tentu remaja putri yang mempunyai status gizi normal tidak mengalami defisiensi zat besi ataupun mineral. Andriani dan Wirjatmadi (2012) mengatakan bahwa faktor-faktor pendorong anemia pada remaja putri adalah adanya penyakit infeksi yang kronis, menstruasi yang berlebihan pada remaja putri, perdarahan yang mendadak seperti kecelakaan, jumlah makanan atau penyerapan diet yang buruk.

c. Hubungan antara Asupan Zat Gizi dengan Kejadian Anemia

Tabel 10 Hubungan Asupan Energi dengan Kejadian Anemia

\begin{tabular}{ccccccc}
\hline $\begin{array}{c}\text { Kejadian } \\
\text { Anemia }\end{array}$ & \multicolumn{2}{c}{ Asupan Energi } & $\begin{array}{c}\text { Koefisien } \\
\text { Defisit Kurang Sedang }\end{array}$ & $\begin{array}{c}\text { Korelasi } \\
\text { (r) }\end{array}$ & $\begin{array}{c}\text { Nilai } \\
\mathrm{p}\end{array}$ \\
\hline $\begin{array}{c}\text { Tidak } \\
\text { anemia }\end{array}$ & 45 & 2 & 3 & & \\
Anemia & 19 & 2 & 0 & 0,058 & 0,889 \\
\cline { 1 - 4 } Jumlah & 64 & 4 & 3 & & \\
\cline { 1 - 2 } & &
\end{tabular}

Sumber : Analisis data primer 2016

Pada tabel 10 diatas didapatkan bahwa sebagian besar subyek tidak anemia memiliki asupan energi dalam kategori defisit yaitu sebanyak 45 subyek. Begitu juga subyek anemia sebagian besar memiliki asupan energi yang defisit sebanyak 19 orang. Dan hasil analisis uji hubungan antara asupan energi dengan kejadian anemia didapatkan nilai $p=0,889$ yang artinya tidak ada hubungan antara asupan energi dengan kejadian anemia. zinc sampai dengan vitamin $\mathrm{C}$, Hal sejalan dengan teori yang menyatakan bahwa gangguan gizi yang

Tabel. 11 Hubungan Asupan Karbohidrat dengan Kejadian Anemia

\begin{tabular}{|c|c|c|c|c|c|c|}
\hline \multirow[b]{2}{*}{$\begin{array}{c}\text { Kejadian } \\
\text { Anemia }\end{array}$} & \multicolumn{4}{|c|}{ Asupan Karbohidrat } & \multirow{2}{*}{$\begin{array}{c}\text { Koefisie } \\
\text { n } \\
\text { Korelasi } \\
\text { (r) }\end{array}$} & \multirow[b]{2}{*}{$\begin{array}{l}\text { Nilai } \\
\text { p }\end{array}$} \\
\hline & $\begin{array}{c}\text { Defisi } \\
\mathrm{t}\end{array}$ & $\begin{array}{c}\text { Kuran } \\
\mathrm{g}\end{array}$ & $\begin{array}{c}\text { Sedan } \\
\mathrm{g}\end{array}$ & $\begin{array}{c}\text { Bai } \\
\text { k }\end{array}$ & & \\
\hline $\begin{array}{c}\text { Tidak } \\
\text { anemia }\end{array}$ & 42 & 4 & 2 & 2 & \multirow{3}{*}{0,311} & \multirow{3}{*}{$\begin{array}{c}0,36 \\
9\end{array}$} \\
\hline $\begin{array}{c}\text { Anemi } \\
\mathrm{a} \\
\end{array}$ & 19 & 2 & 0 & 0 & & \\
\hline Total & 61 & 6 & 2 & 2 & & \\
\hline
\end{tabular}

Sumber : Analisis data primer 2016

Subyek dengan kategori tidak anemia sebagian besar memiliki asupan karbohidrat defisit yaitu sebesar 42. Begitu juga subyek anemia sebagian besar memiliki asupan karbohidrat yang defisit sebanyak 19 orang. Hasil analisis uji hubungan antara asupan karbohidrat dengan kejadian anemia didapatkan nilai $\mathrm{p}=0,369$ yang memiliki arti tidak ada hubungan antara asupan karbohidrat dengan kejadian anemia.

Tabel 12 Hubungan Asupan Lemak dengan Kejadian Anemia

\begin{tabular}{|c|c|c|c|c|c|c|}
\hline & \multirow{2}{*}{\multicolumn{4}{|c|}{ an Lemak }} & \multirow{3}{*}{$\begin{array}{c}\text { Koefisie } \\
\mathrm{n} \\
\text { Korelasi } \\
(\mathrm{r})\end{array}$} & \multirow[b]{3}{*}{$\begin{array}{c}\text { Nilai } \\
\mathrm{p}\end{array}$} \\
\hline \multirow[b]{2}{*}{$\begin{array}{c}\text { Kejadian } \\
\text { Anemia }\end{array}$} & & & & & & \\
\hline & $\begin{array}{c}\text { Defisi } \\
\mathrm{t}\end{array}$ & $\begin{array}{c}\text { Kuran } \\
\mathrm{g}\end{array}$ & $\begin{array}{c}\text { Sedan } \\
\mathrm{g}\end{array}$ & $\begin{array}{c}\mathrm{Bai} \\
\mathrm{k}\end{array}$ & & \\
\hline \multirow{2}{*}{$\begin{array}{c}\text { Tidak } \\
\text { anemia } \\
\text { Anemi } \\
\text { a }\end{array}$} & 44 & 3 & 2 & 1 & \multirow{3}{*}{0,272} & \multirow{3}{*}{$\begin{array}{c}0,44 \\
2\end{array}$} \\
\hline & 17 & 1 & 2 & 1 & & \\
\hline Total & 61 & 4 & 4 & 2 & & \\
\hline
\end{tabular}

Sumber : Analisis data primer 2016

Pada tabel 12 diatas diketahui bahwa subyek dengan kategori tidak anemia sebagian besar memiliki asupan lemak defisit yaitu sebesar 44 . Begitu juga subyek anemia sebagian besar memiliki asupan lemak yang defisit sebanyak 17 orang. Hasil analisis uji hubungan antara asupan lemak dengan kejadian anemia didapatkan nilai $\mathrm{p}=0,442$ yang artinya tidak ada hubungan anatara asupan lemak dengan kejadian anemia.

Tabel 13 Hubungan Asupan Protein dengan Kejadian

\begin{tabular}{|c|c|c|c|c|c|c|}
\hline \multirow[b]{3}{*}{$\begin{array}{l}\text { Kejadian } \\
\text { Anemia }\end{array}$} & \multicolumn{6}{|c|}{ Anemia } \\
\hline & & Asupan & rotein & & Koefisie & \\
\hline & $\begin{array}{c}\text { Defisi } \\
t\end{array}$ & $\begin{array}{c}\text { Kuran } \\
\mathrm{g}\end{array}$ & $\begin{array}{c}\text { Sedan } \\
\mathrm{g}\end{array}$ & $\begin{array}{c}\text { Bai } \\
k\end{array}$ & $\begin{array}{c}\mathrm{n} \\
\text { Korelasi } \\
(\mathrm{r})\end{array}$ & $\begin{array}{c}\mathrm{Nila} \\
\mathrm{p}\end{array}$ \\
\hline $\begin{array}{c}\text { Tidak } \\
\text { anemia }\end{array}$ & 37 & 6 & 4 & 3 & & \\
\hline $\begin{array}{c}\text { Anemi } \\
\text { a }\end{array}$ & 13 & 2 & 4 & 2 & 0,271 & $\begin{array}{c}0,28 \\
0\end{array}$ \\
\hline Total & 50 & 8 & 8 & 5 & & \\
\hline
\end{tabular}

Sumber : Analisis data primer 2016

Pada tabel 13 diatas di dapatkan bahwa sebagian besar subyek dengan kategori tidak anemia memiliki asupan protein dalam kategori defisit yaitu sebesar 37 subyek. Begitu juga subyek anemia sebagian besar memiliki asupan protein yang defisit sebanyak 13 orang. Dan hasil analisis uji hubungan antara asupan protein dan kejadian anemia bernilai $\mathrm{p}=$ 0,280 yang artinya tidak ada hubungan antara asupan protein dengan kejadian anemia

Tabel 14 Hubungan Asupan Vitamin C dengan Kejadian Anemia

\begin{tabular}{lcccc}
\hline \multirow{2}{*}{ Kejadian Anemia } & \multicolumn{3}{c}{ Asupan Vitamin } & \multicolumn{2}{c}{$\begin{array}{c}\text { Koefisien } \\
\text { Korelasi } \\
\end{array}$} & \multicolumn{2}{c}{ C } & Nilai p \\
\cline { 2 - 3 } & Defisit & Sedang & $(\mathrm{r})$ & \\
\hline Tidak anemia & 48 & 2 & & \\
Anemia & 20 & 1 & 0,091 & 0,888 \\
\cline { 1 - 3 } Total & 68 & 3 & & \\
\hline
\end{tabular}

Sumber : Analisis data primer 2016 
Sebagian besar subyek dengan kategori tidak anemia memiliki asupan vitamin $\mathrm{C}$ dalam kategori defisit yaitu sebesar 48 subyek. Begitu juga subyek

vitamin $\mathrm{C}$ dan kejadian anemia bernilai $\mathrm{p}=0,888$ yang artinya tidak ada hubungan antara asupan energi dengan kejadian anemia.

Dari hasil analisis seluruh asupan yang diteliti yaitu asupan energi, asupan lemak, asupan karbohidrat, asupan protein, dan asupan vitamin $\mathrm{C}$ menggunakan uji Gamma didapatkan tidak terdapat hubungan yang signifikan dengan kejadian anemia pada remaja di SMK Mahfilud Duror II.

Dari hasil wawancara recall diketahui bahwa siswi SMK Mahfilud Durror II sering mengkonsumsi teh manis dan hampir setiap hari mengkonsumsi junk food berupa sosis, sebagian dari siswi juga sedang berusaha mengurangi berat badan atau berdiet sehingga memungkinkan status gizi normal tetapi tidak menyingkirkan kejadian anemia. Kebiasaan mengkonsumsi jenis makanan yang sama menyebabkan siswi SMK Mahfilud Durror II tanpa sadar telah membatasi asupan vitamin dan mineral yang menyebabkan kemungkinan terjadinya anemia semakin besar. Dan konsumsi protein nabati yang lebih dominan juga menjadi salah satu penyebab terjadinya anemia meskipun dalam keadaan status gizi normal, hal ini disebabkan zat besi yang terkandung dalam protein nabati bersifat non heme sehingga sulit dicerna.

Beberapa faktor yang berhubungan dengan kejadian anemia pada remaja putri, yaitu asupan energi, asupan protein, asupan zat besi, asupan vitamin $\mathrm{C}$, kebiasaan minum teh atau kopi, investasi cacing, pengetahuan, pendidikan dan jenis pekerjaan orang tua, pendapatan keluarga, dan pola menstruasi. Meningkatnya konsumsi makanan olahan yang nilai gizinya kurang, namun memiliki banyak kalori Konsumsi jenis-jenis junk food merupakan penyebab para remaja rentan sekali kekurangan zat gizi (Istiany \& Rusilanti, 2013).

Menurut Carson (2008) bagi remaja, makanan merupakan suatu kebutuhan pokok untuk pertumbuhan dan perkembangan tubuhnya. Kekurangan konsumsi makanan baik secara kuantitatif maupun kualitatif, akan menyebabkan gangguan proses metabolisme tubuh, yang mengarah pada timbulnya suatu penyakit. Tidak ada satupun jenis makanan yang mengandung gizi lengkap, maka remaja harus mengkonsumsi makanan yang beraneka ragam, kekurangan zat gizi pada jenis makanan yang satu akan dilengkapi oleh zat gizi dari makanan lainnya. Pada penelitian ini untuk mengetahui hasil asupan zat gizi melalui recall atau anamnesa kebutuhan zat gizi yang di konsumsi setiap hari, tidak dilakukan secara proses kimiawi metabolisme.

\section{KESIMPULAN}

Dari penelitan ini didapatkan kesimpulan tidak terdapat hubungan antara status gizi dengan kejadian anemia pada remaja putri di SMK Mahfilud Duror II Jelbuk dan keeratan hubungannya lemah.Tidak terdapat hubungan antara asupan zat gizi dengan kejadiant anemia pada remaja putri di SMK Mahfilud duror II Jelbuk

Peneliti selanjutnya diharapkan dapat menambah variabel penelitian mengenai faktor lain yang mungkin menyebabkan anemia seperti infeksi cacing, pengetahuan dan sikap siswi terhadap status gizi dan kejadian anemia serta pendidikan dan jenis pekerjaan orang tua, pendapatan keluarga, dan juga pola menstruasi. dengan kategori anemia sebagian besar memiliki asupan vitamin $\mathrm{C}$ yang defisit sebanyak 20 orang. Dan hasil analisis uji hubungan antara asupan

\section{DAFTAR PUSTAKA}

Aru W S, Bambang S H, Idrus A, Marcelinus S K, Siti S. 2006. Pendekatan terhadap pasien anemia. Buku ajar Ilmu Penyakit Dalam. Jilid II Edisi IV.Halaman 622 - 626. Pusat Penerbitan Ilmu Penyakit Dalam Fakultas Kedokteran Universitas Indonesia. Jakarta.

Carson, V. B (2008). Mental Health Nursing :The Nurse Patient Journey Philadelphia :W.B. Saunders Company

Departemen Kesehatan Republik Indonesia, 2008. LaporanHasil Riset Kesehatan Dasar Indoneaia Tahun 2007.Jakarta.

Depkes RI. 2010. Keputusan Menteri Kesehatan Republik Indonesia Tentang Standar Antropometri Penilaian Status Gizi Anak

Hankusuma, A W. 2009. Skrining Anemia Terhadap Remaja Putri pada Tahun Pertama Menstruasi di Kecamatan Mulyorejo. www.adln.fkm.unair.ac.id diakses tanggal 2 Agustus 2016

Hapzah., Y R. 2012. Hubungan Tingkat Pengetahuan dan Status Gizi Terhadap Kejadian Anemia Remaja Putri pada Siswi Kelas III di SMAN 1 Tinambung Kabupaten Polewali Mandar. Media Gizi Pangan vol. XIII edisi 2. STIKES Bina Bangsa Majene

Kristiyanasari, W. 2010. Gizi Ibu Hamil. Yogyakarta : Nuha Medika

Istiany, A dan Rusilanti. 2013. Gizi Terapan. Bandung: PT. Remaja Rosdakarya.

Kementerian Kesehatan Republik Indonesia. 2013. Riset Kesehatan Dasar 2013. Jakarta. Badan Penelitian dan Pengembangan Kesehatan Kementerian Kesehatan Republik Indonesia.

Manuaba, IBG. 2007. Pengantar Kuliah Obstetri. Jakarta: EGC

Mariana, W.,Khafidhoh, N. 2013. Hubungan Status Gizi dengan kejadian Anemia pada Remaja Putri di SMK Swadaya Wilayah Kerja Puskesmas Karangdoro kota Semarang. Jurnal kebidanan Vol.2 No.4 ISSN. 20897669. Poltekkes Kemenkes Semarang

Marmi. 2013. Gizi dalam Kesehatan Reproduksi. Yogyakarta : Pustaka Pelajar

Potter, P.A.,Perry, A.G. 2005. Buku Ajar Fundamental Keperawatan : Konsep, Proses, dan Praktik. Edisi 4 Volume 2. Alih bahasa : Renata Komalasari,dkk. Jakarta : EGC

Proverawati, A, dan Kusumawati, E. 2010. Ilmu Gizi untuk Keperawatan dan Gizi Kesehatan. Yogyakarta : Nuha Medika

Soetjiningsih. 2012. Tumbuh Kembang Anak. Jakarta: EGC

Sulistyoningsih, H. 2011. Gizi Untuk Kesehatan Ibu dan Anak. Edisi 1. Yogyakarta: Graha Ilmu.

Supariasa, IDN, Bachyar B, Ibnu F. 2012. Penilaian Status Gizi. Jakarta: EGC 